УДК 94:316.662-055.2(497.11)"1941/1944"

305-055.2(497.11)"1941/1944"

331.5-055.2(497.11)"1941/1944"

DOI https://doi.org/10.31212/tokovi.2020.3.sko.69-95

Оригинални научни рад

Примљен: 4. 3. 2020.

Прихваћен: 1.10. 2020.

Ljubinka ŠKODRIĆ

Institute for Contemporary History, Belgrade

lj.skodric@gmail.com

\title{
Women and Wage Labor in Occupied Serbia 1941-1944. Policy of Collaborationist Government and German Occupation Authorities
}

\begin{abstract}
The article analyzes the conditions of the participation of women on the job market in occupied Serbia in the course of the World War II. Its focus is on the policy of the local collaborationist government and the attitudes of the German occupation authorities regarding female employment and the working conditions of employed women, the possibilities and forms of their employment, and the position of the female workforce. This research is conducted on the basis of archival material, wartime press, and literature.

KEY WORDS: Women, Work, Employment, Voluntary Work, Mandatory Work, Female Civil Servants, Female Educational Workers, Occupation, Collaboration, World War II
\end{abstract}

The concept of work has changed its meaning in different historical periods and within different social and cultural contexts. Broadly speaking, work can be seen as conscious and purposeful human activity by means of which a person transforms nature and influences others for the purpose of satisfying his own needs and the needs of the community. ${ }^{1}$ Employment options, wages, and working conditions are also significantly determined by gender relations. Therefore, the participation of wom-

1 Božo Milošević, Sociološki temati o radu, obrazovanju i kulturi, (Novi Sad: Prometej, Niš: Filozofski fakultet, 2016), 39. 
en and men in paid work and the social value of their work, represent the key determinants of their social status. ${ }^{2}$

The employment of a great number of women in World War I and World War II due to a shortage of male labor strongly influenced a change in the position of women on the job market. This was a precedent that probably only accelerated the already existing trends of entry of women into the world of work. It made such an impact that women started to appreciate their potentials more, increase self-confidence, and develop the belief that they had the right to work. ${ }^{3}$

In the first half of the $20^{\text {th }}$ century, the social position of women in Serbia was strongly determined by patriarchal family and social relations, as well as traditional morals. ${ }^{4}$ An agrarian society, which the Kingdom of Yugoslavia was, had an impact on marginalizing the female labor force and was not conducive to the massive appearance of women in the labor market. Compared to the enormous amount of women's unpaid labor in the fields and in their homes, there were very few employed women, who were forced to work in order to survive. After World War I, women were more involved in production and one of the reasons for that was the massive loss of the male population in the previous wars. The number of employed women kept increasing even though these women represented mainly an unqualified labor force whose earnings were insufficient even for the most basic needs. ${ }^{5}$ According to the data on socially insured persons, on the territory of the Kingdom of Yugoslavia in 1940, the total number of employed women was 199,077 , or $17 \%$ of the total number of employees. ${ }^{6}$ Expressed in percentages, the greatest number of women worked in agriculture, the textile industry, and as house servants. ${ }^{7}$ Additionally, a certain number of women were engaged in educational and health activities.

2 Branka Galić, „Žena i rad u suvremenom društvu - značaj 'orodnjenog' rada“, Sociologija i prostor 48/2011, 27.

3 Deborah Simonton, A History of European Women's Work. 1700 to the Present, (London, New York: Routledge, 1998), 186.

4 Вера Гудац Додић, „Запошљавање жена у Србији и Југославији у другој половини 20. века“, Годишњак за друштвену историју 1-3, (2003), 87.

5 Milica Milenković, „Žene radnice u privredi Srbije 1918-1929. godine”, Srbija u modernizacijskim procesima 19. i 20. veka. Položaj žene kao merilo modernizacije II, naučni skup, ur. Latinka Perović, (Beograd: Institut za noviju istoriju Srbije, 1998), 223.

6 Neda Božinović, Žensko pitanje u Srbiji u XIX i XX veku, (Beograd: „Devedesetčetvrta“, „Žene u crnom“, 1996), 230.

7 Jovanka Kecman, Žene Jugoslavije u radničkom pokretu i ženskim organizacijama 1918-1941, (Beograd: Institut za savremenu istoriju, Narodna knjiga, 1978), 34. 
The occupation of Serbia in the course of World War II brought changes into the world of work of employed women as well as of those who, except for unpaid housework, had to seek employment due to harsh material conditions. Among these women, there were many unqualified workers, mainly laborers. In October of 1941, they represented 34.6\% of all unemployed laborers. ${ }^{8}$ The possibilities of employment for women were significantly impacted by irregular circumstances and wartime events. Huge numbers of war prisoners, the participation of men in military detachments, as well as the departure from Serbia of those workers who had come from other regions and the deportation of workers from Serbia to Germany, caused significant shortage of labor force. ${ }^{9}$ According to certain data, the number of workers within the economy in occupied Serbia was no more than 160.000 , but even that number kept decreasing gradually as a consequence of an insufficient supply of basic foodstuffs and because of uprisings. ${ }^{10}$

The collaborationist authorities pointed out the importance of work. This rhetoric, up to a large extent, was in accordance with the interests of the occupiers. According to the standpoints of the collaborationist authorities, work had manifold significance. It was seen as a means for providing an existence for the Serbian nation, but its political and educational role was also taken into account. In this respect, work also represented a kind of support to the authorities. It was way of maintaining order and peace and fulfillment of economic and political expectations of the occupier, but also a vehicle for promoting the traditional world view of the collaborationist government of Milan Nedić. ${ }^{11}$ On the other hand, while the occupier was interested in the full labor mobilization of the population, the collaborationist authorities did not have trust in women's labor even though they glorified work. This distrust stemmed from tradi-

$8 \quad 3.787$ unemployed male labourers and 2.004 female labourers were looking for the job in this month. Милица Миленковић, Тома Миленковић, Запошљавање у Cpбијu, I: Од зачетака до ослобођења земље 1944, (Београд: Републички завод за тржиште рада, 2002), 304.

9 Zoran Janjetović, Collaboration and Fascism Under the Nedić Regime, (Belgrade: Institute for Recent History of Serbia, 2018), 257.

10 Драган Алексић, Привреда Србије у Другом светском рату, (Београд: Институт за новију историју Србије, 2002), 325.

11 Зоран Јањетовић, „'На радним задацима'. Рад на страницама колаборационистичке штампе“, Колаборационистичка штампа у Србији 1941-1944, прир. Александар Стојановић, (Београд: Филип Вишњић, 2015), 345. 
tional views regarding the role of women in society. ${ }^{12}$ Nevertheless, on the territory of occupied Serbia women were employed to a considerable extent and the occupation brought new possibilities for their employment, including their work in the institutions of the occupation system or going to Germany for the purpose of finding employment.

\section{The Occupier as the Employer}

The German occupation forces also incited a more significant work engagement of the local population by engaging the local population as support staff. Many women worked for the German occupation authorities as translators, secretaries, typists, cooks, cleaners, as well as intelligence liaisons. At the very beginning of the occupation, certain women, primarily those employed as support staff in Yugoslav Army headquarters, were forced to work in the same capacity for the needs of the occupation troops, even as unpaid forced labor. At the beginning, the service was not adequately compensated by the occupier. It was mainly avoided, considered as humiliating, and women who accepted it were those who did not have other ways of earning a living. ${ }^{13}$ Working for the German forces also meant closer contacts with them and possible intimate relationships, which sometimes happened..$^{14}$

12 The contribution of women to keeping their households and cultivation of land was pointed out in the collaborationist press during the occupation. Primarily it was emphasized that women mostly contributed to the homeland as housewives and mothers. Explained in more detail in: Љубинка Шкодрић, „'Друштвена одговорност српске жене за наш државни слом'. Женско питање у колаборационистичкој штампи“, Колаборационистичка штампа у Србији 1941-1944, 289-311.

13 One of the women to whom the president of the municipality in Smederevska Palanka offered help to start working for the German forces responded to him: "Why doesn't your wife get employed as well if it is so good?" She was punished with three days of imprisonment because of this comment. Arhiv Srbije (Archives of Serbia - AS), Zbirka dokumenata Bezbednosno-informativne agencije (BIA), I-36.

14 Milena Spasić, interpreter of Feld Command in Užice and Šabac and subsequently an interpreter for the Gestapo, had a love affair with Paul William, head of the Gestapo in Šabac, "to whom she entirely gave her soul and body and even traveled with him to Germany and spent about two months in Ulm in the course of the summer 1942." AS, Zemaljska komisija Srbije za utvrđivanje zločina okupatora i njihovih pomagača 1944-1948 (G-25), f. 9, zl. br. 1755.

The Ravna Gora Movement collected data on the behaviour of Spasić considering that her two brothers were general staff officers and war prisoners in Nuremberg. After liberation, Spasić moved out with the German Army while her case was transferred from the court for processing crimes and misdemeanours against Serbian national honour in Užice to the jurisdiction of the military court together with several statements that she had not participated in any denunciations. 
Women working for the occupation forces were very often very close to them ideologically. Many women who had not been politically oriented, after being employed by the German occupier, started to advocate the interests of the occupier. ${ }^{15}$ Not only did they support the occupier's war successes, but they also frequently established intelligence cooperation with them. Additionally, the most prominent intelligence role and the greatest trust of the occupier went to those women who had been working for the German intelligence service before the war, such as Olga Belagić, Marion Bauderer, and Vera Pešić. The Yugoslav authorities arrested them for their intelligence activities even before the occupation - and the first two were in prison once the occupation started. ${ }^{16}$

The German institutions that employed the local population previously had the Gestapo check their political reliability. ${ }^{17}$ There were many Russian émigrés among the employed women, who stood out due to their command of more languages, which made it easier for them to find employment and which was an advantage on the labor market. ${ }^{18}$ In fact, the women who were fluent in German and worked as interpreters for Germans had the greatest privileges and best reputation among the occupation authorities. German language proficiency, as well as self-confidence, eloquence, and vigor, were the highest prized personal traits of women hired by the occupation apparatus. Anka Bajčetić, an interpreter of the city magistrate in Niš had such a special reputation. ${ }^{19}$ She often intervened with the German authorities in favor of arrested citizens. In most cases, the local population expected such interventions from women in these positions, which exposed them to intensive pressure. In many cases, mediation was almost impossible, which caused discontent. ${ }^{20}$ Furthermore, the

15 Two women working as cooks for the German forces in Topola were politically inactive before the war but after they got the employment, they began to praise Nazi war invincibility and publicly dated and lived with German soldiers. AS, BIA, I-7.

16 Istorijski arhiv Beograda (Historical Archives of Belgrade - IAB), Zapovednik policije bezbednosti i službe bezbednosti (BdS), В-269; Венцеслав Глишић, „Досије о Вери Пешић или како не треба писати историју обавештајца“, Војноисторијски гласник 2/2009, 178.

17 IAB, BdS, B-73; IAB, BdS, D-46.

18 Natalija Gontačev, the daughter of a Russian general, sought employment in German institutions and got it in the administrative headquarters. She spoke Serbian, French, German, and Russian. Positive reference was also given by BdS for Irena Erohina. IAB, BdS, E-4; IAB, BdS, G-144.

19 According to her own words, Bajčetić established cooperation with the National Liberation Movement no later than in 1941. AS, BIA, IV-2.

20 Milena Spasić, as an interpreter in the branch office of the Gestapo for Šabac, was expected to intervene for Vera Blagojević and Momcilo Mihajlović who were known 
influence of these women had its limits. When interpreter Nataša Frnjčević interceded with the Gestapo for the release of some arrested citizens, she was told that if she made any more appeals, she too would be arrested. ${ }^{21}$

Women working for the occupation authorities were frequently reported for obtaining material gain from interventions and mediation with the occupier for the purpose of releasing arrested persons. These offenses were frequent and could turn into continuous extortion. ${ }^{22}$ It mainly remained unclear in the course of the investigation whether the accused women really had the power and influence to mediate in having the prisoners released and they were often accused of unjustifiably extorting money or material gain. Nevertheless, many reported cases were not investigated diligently, the real possibility of intervening for the purpose of releasing remained unclear, and there was a noticeable tendency of putting the complete blame on the accused women. ${ }^{23}$ Many of them were also exposed to public humiliation. ${ }^{24}$

\section{Voluntary Work in Germany}

Apart from being employed in the institutions and offices of the occupation administration, workers from Serbia also had the opportunity of going to work in Germany. Moreover, fewer numbers of men participating in the labor force in occupied Serbia opened new possibilities for employment of women and contributed to their more favorable position on the labor market when compared to previous periods. Qualified female workers, who were relatively few in Serbia, were particularly valued, whereby they were in a more favorable position with respect to pos-

as communists and members of National Liberation Movement. AS, G-25, f. 9, zl. br. 1755.

21 AS, BIA, I-7.

22 The woman who worked as an interpreter for the Gestapo in Leskovac after the war was accused of blackmailing the families of the arrested and also of taking food and money from them for the said interventions with the German authorities. Others were even accused for contributing to the detention of the arrested in prison by means of their translation. AS, G-25, f. 124, zl. br. 16276; AS, G-25, f. 125, zl. br. 163866.

23 IAB, BdS, G-699.

24 In May of 1943, a cleaning woman working in the branch office of the Gestapo in Požarevac had to pass through the procession together with three prisoners followed by a gendarme and a drummer holding a sign that said she had done harm to the people by presenting herself as the registrar of the Gestapo and extorting money by promising that arrested people would be released. Саша Марковић, Стазама смелих. Монографија народноослободилачког рата на подручју општине Пожаревац, (Пожаревац: Културно просветна заједница општине Пожаревац, 1979), 328. 
sibilities of employment. They also had better incomes since in the course of the occupation earnings of workers were significantly higher compared to earnings of civil servants employed in the local administration. ${ }^{25}$

The use of foreign labor in the Third Reich was partially a consequence of the tendency to avoid the strict application of provisions regulating the obligatory work of German women, since there was an endeavor to spare them..$^{26}$ Among the foreign workers in the Third Reich, there were almost 2 million women, mainly from the Soviet Union and Poland. ${ }^{27}$ Within the hierarchy established by the Nazi authorities with respect to foreign workers, male and female workers from Serbia had a better position when compared to the workers from the Soviet Union and Poland, and they enjoyed a similar status as workers from the occupied areas of France, the Netherlands, or Belgium. ${ }^{28}$

Due to insufficient preserved historical sources, it is difficult to determine the exact number of workers from Serbia who moved to Germany, but separate information can be pieced together to get a basic idea. Before the end of August 1941, around 17,800 men and 4,800 women from Serbia went to work in Germany. ${ }^{29}$ According to data from 31 August 1942, a total of 43,906 people committed themselves to working in Germany. Out of that number, $26,268(20,161$ men and 6,107 women) were employed in industry and 17,638 (13,310 men and 4,328 women) in agriculture. ${ }^{30}$ The overall number of women from Serbia employed in Germany in October of 1942 was 15,001 , but it declined over time so that on 30 September 1944 it was $8,415 .^{31}$

25 Наташа Милићевић, „Исхрана у окупираном Београду 1941-1944“, Токови истоpuje 2/2012, 87.

26 Mark Mazover, Mračni kontinent. Evropa u dvadesetom veku, (Beograd: Arhipelag, 2011), 175.

27 Matthew Stibbe, Women in the Third Reich, (London: Bloomsbury Academic, 2003), 101.

28 Their status was also significantly determined by the fact that they represented a relatively small group of workers. Sanela Schmid, "Serbian Civilian Workers in Nuremberg 1941-1945", Forced Labour in Serbia. Producers, Consumers and Consequences of Forced Labour 1941-1944, eds Milovan Pissari, Sanela Schmid, (Belgrade: Center for Holocaust Research and Education, 2018), 103-104.

29 Muharem Kreso, Njemačka okupaciona uprava u Beogradu 1941-1942. Sa osvrtom na centralne okupacione komande i ustanove za Srbiju, Jugoslaviju i Balkan, (Beograd: Istorijski arhiv Beograda, 1979), 124.

30 Драган Алексић, „Проблем радне снаге у индустрији и рударству Србије у Другом светском рату“, Токови историје 3-4/1997, 97.

31 These numbers in German statistics refer to the former territory of the Kingdom of Yugoslavia without the ISC (Independent State of Croatia). Schmid, "Serbian Civilian Workers", 85. 
Just as in France, where women who had gone to work in Germany were considered to be of dubious morals, ${ }^{32}$ certain Serbian collaborators had a similar stigma. ${ }^{33}$ Starting from April of 1942, a delegation for Serbian workers and prisoners was active in Berlin, within the German Labor Front (DAF). Milan Kečić, the clerk of the Ministry of the People's Economy was at the head of this delegation. In the course of 1942, he visited the Serbian female workers in the vicinity of Vienna. In a report on his visit, Kečić stated that among the workers were those with venereal diseases, and he ordered their mandatory medical inspection. Another problem for these women workers was that they shared sleeping quarters with women workers from Croatia, with whom they did not have good relationship, which resulted in a decision on their accommodations being separate. ${ }^{34}$ In the example of women from Serbia working in Nuremberg, it can be seen that they were returned back home in case of any disease. On the other hand, despite the strict punishment of engaging in sexual intercourse with Germans, there also were exceptions, and even marriages between Germans and women workers from Serbia. ${ }^{35}$

In 1942 and 1943 the press in occupied Serbia published several articles about Serbian workers in Germany. The easier work and more advantageous conditions of life and work were praised, emphasizing that the Serbian women participated in supporting the Third Reich. ${ }^{36}$ The description of the lives of Serbian women working in Germany also included praise for the fact that the "Serbian woman is a good housewife even abroad" and that the struggle to sustain the family was the primary motive for going to work abroad. ${ }^{37}$ It was pointed out that considerable num-

32 Richard Vinen, The Unfree French. Life under the Occupation, (London: Penguin, 2007), 286.

33 According to the data of the Yugoslav Government-In-Exile, Cvetan Ceka Đorđević, assistant minister of internal affairs in the collaborationist government, gave support to Serbian women to go to Germany to work and in response to their expressed fear that they could be exposed to prostitution there, he allegedly said: "If they can make out at Kalemegdan Park and in Belgrade cinemas, they can also serve as a pastime to German soldiers who are fighting for the freedom of Europe." Arhiv Jugoslavije (Archives of Yugoslavia - AJ), Emigrantska vlada Kraljevine Jugoslavije 1941-1945 (103), 27-235.

34 AS, Predsedništvo Ministarskog saveta 1941-1944 (G-1), f. 3, br. 62/42.

35 Schmid, "Serbian Civilian Workers", 91.

36 „Берлинска писма 'Обнови'. Посета логорима наших радника у Бохуму“, Обнова, 9. 4. 1942, 4; „Како живе наши у страном свету... Посета логорима српских радника у Западној Немачкој - Женски раднички станови у Валсродеу убрајају се међу најмодерније у Европи“, Обнова, 28. 3. 1942, 5.

37 „Српска жена-мајка на раду у Немачкој“, Ново време, 11. 12. 1943, 3. 
bers of Serbian male and female workers arrived in Germany since honest work and adequate reward was offered there to "all hard-working hands." The diligence of women and their desire for gaining knowledge and proving themselves as good workers was also emphasized. ${ }^{38}$ Nevertheless, this idealized presentation of the conditions of life and work of male and female workers in Germany was not a realistic depiction of the situation. In reality, enforcement, isolation, insufficient payment, and inadequate accommodation were the main characteristics of life of foreign workers in Germany. ${ }^{39}$

\section{Mandatory Work}

Even though women went to Germany voluntarily, their stay there could be prolonged, changing their work status from voluntary to forced. ${ }^{40}$ There were also failed attempts to impose mandatory work for women within occupied Serbia. At the end of 1941, the National Service for the Renewal of Serbia was established on the territory of occupied Serbia which envisaged six-month mandatory work on the restoration of Serbia for men from 17 to 45 years of age. ${ }^{41}$ Women were exempted from mandatory work for the National Service for Renewal. It was stated that such practice was applicable in Germany but it was pointed out that it would be contrary to the national mentality in Serbia and that it would cause disorders due to the separation of girls from their homes and the environment to which they belong in accordance with tradition. ${ }^{42}$ An example that was commendably highlighted was that of Hungarian women engaged in performing tasks related to national defense along with the possibility of choosing the type of jobs they wanted to perform. ${ }^{43}$ Unlike other parts of occupied Serbia, Volksdeutchers (ethnic Germans) in Banat had their working service, which was an equivalent to the National Ser-

38 „С транспортом српских радника на путу у Немачку. Нова сеоба народа“, Обнова, 21. 2. 1942, 5 .

39 Mark Mazover, Hitlerovo carstvo. Nacistička vladavina u okupiranoj Evropi, (Beograd: Arhipelag, 2019), 317-319.

40 Even though they had concluded employment agreements, starting from the October of 1942, foreign workers could be retained upon the expiry of these agreements. Schmid, "Serbian Civilian Workers", 87.

41 „Уредба о увођењу Националне службе за обнову Србије“, Службене новине, 16. 12. $1941,1$.

42 „За обнову Србије. Ствара се 'школа живота' за нашу младеж. У чему се састоји радна служба омладине“, Обнова, 12. 7. 1941, 3.

43 „Мађарске жене у служби рада“, Ново време, 21. 5. 1942, 2. 
vice for Renewal. Girls were hired in it as well, and there were also four female labor camps. ${ }^{44}$

However, certain women in the course of the occupation fell under the provisions of mandatory work. They had to serve as a replacement for male members of the family who wanted to avoid the obligation of unpaid forced labor. ${ }^{45}$ Women also voluntarily replaced their husbands who had a working obligation so that they undertook their regular tasks and ran their shops. ${ }^{46}$ Starting from September 1942, female doctors participated in mandatory work since the Regulation on Mandatory work of Doctors envisaged mandatory work for all doctors notwithstanding gender, except doctors older than 70 and female doctors with children younger than 18, who could also be called to work, primarily for the purpose of participation in combating epidemics. ${ }^{47}$

At the end of 1941, a Regulation on Mandatory Work and Restriction of Freedom of Employment came into effect. ${ }^{48}$ It envisaged that all citizens from 17 to 45 years of age could be invoked to mandatory work regardless of whether they were employed or not at that moment. The provisions of this Regulation did not apply to women. The changes occurred in March of 1943 when the war economy measures of the Reich were introduced and when complete economic mobilization of the conquered territories had commenced. The second regulation for implementing the Regulation on introducing the war and economic measures of the Reich, published in March of 1943 exempted, among others, the owners of agricultural farms and their spouses from mandatory work, male and female students, as well as women who were pregnant or had one child of preschool age or two children under 14 years of age. A separate article regulated the fact that unmarried women aged 21 to 35 could also be sent for mandatory work to Germany. ${ }^{49}$ However, such applications of women who fell under the mandatory working service were received by a considerable public resentment..$^{50}$ Dissatisfaction was calmed down by the admin-

44 Zoran Janjetović, U skladu sa nastalom potrebom... Prinudni rad u okupiranoj Srbiji 1941-1944, (Beograd: Institut za noviju istoriju Srbije, 2012), 206.

45 Ibid., 55.

46 „Жене замењују мужеве на послу“, Ново време, 12. 5. 1943, 4.

47 „Уредба о обавезном раду лекара“, Службене новине, 1. 9. 1942, 1.

48 „Уредба о обавезном раду и ограничењу слободе упослења“, Службене новине, 30. 12. 1941, 1.

49 „Србија и тотални рат. Нова овлашћења Генералног опуномоћеника за привреду“, Ново време, 27. 3. 1943, 3.

50 Dragutin J. Ranković recorded in his diary on 2 April 1943: "Our women and girls who might go to Germany are upset. They complain and curse. Terrible! Do we live 
istrator of the city of Belgrade Dragomir Jovanović, who said that women from Serbia were not going to be called for mandatory work to Germany. Even though that was envisaged by the regulation, it was not going to apply to women from Serbia. In one part of his statement, he was imprecise since he stated that Serbian women were not going to be called to work out of Serbia, which nevertheless left open the possibility that they could be called to work on the territory of Serbia. Additionally, he stated that women were going to stay at home to replace male members of the family and that by being good mothers, wives, sisters, and housewives they would "give their greatest contribution to a new Serbia, a European, and social community". 51

In the same period, at the end of 1943, the Labor Market commenced to produce a database of working-age population pursuant to the order of Franz Neuhausen, German general plenipotentiary for the economy of Serbia. ${ }^{52}$ In compliance with the said decree, at the beginning of 1944, the registration of unmarried women born between 1921 and 1925 was initiated as well, thus creating a new wave of dissatisfaction. ${ }^{53}$ The production of this file lasted until the end of the occupation but no concrete measures of working engagement of the population were taken on the basis of it.

There were attempts to engage female labor on a larger scale in order for women to replace men at their workplaces so that these men would be subsequently hired for other types of work. In September of 1943, the Journal of the Regulations for the Occupied Serbian Territory published the Regulation on Replacing Male Workers and Employees by Women. According to this regulation, all companies and public institutions were obliged to examine the possibility of employing women in jobs previously done by men. ${ }^{54}$ Pursuant to the regulation, this replacement was possible in all workplaces where tasks were such that women could be trained to per-

in the time of Huns and Avars?" Свакодневни живот под окупацијом 1941-1944. Искуство једног Београђанина, прир. Наташа Милићевић, Душан Никодијевић, (Београд: Институт за новију историју Србије, 2011), 488.

51 „Изјава министра Драг. Љ. Јовановића о обавезном раду. 'Српске мајке, жене, кћери и сестре неће бити позиване на обавезан рад у Рајх, нити ван територије Србије'“, Ново време, 4. 4.1943, 3.

52 Т. Миленковић, М. Миленковић, Запошљавање у Србији, 324.

53 The press wrote that certain women were forced to reveal their real age due to the decree. „Како су неке Београђанке одједном остариле за неколико година... Прва последица регистрације женских лица“, Обнова, 19. 1. 1944, 4.

54 „Уредба о замењивању мушких радника и намештеника женама“, Лист уредаба за окупирану српску територију, 15. 9. 1943. 
form them within a period of three months, at workplaces in craft shops, workshops, and companies in which women could work after being taught without any hazard to their health, but if tools and objects weighing more than 15 kilograms were to be lifted, such type of work could not be considered suitable for women. Companies and administrative authorities had the obligation to report to the German bodies the number of workers and employees that were going to be replaced by women along with precise personal data. ${ }^{55}$ In order to enable women with small children to work, meetings were to be held with women's associations for the purpose of their engagement in establishing as many kindergartens as possible.

In September of 1943, record-keeping was carried out in Serbian institutions and the possibilities of replacing male with female workers were evaluated. However, many offices did not show willingness to replace men with women. The main arguments pointed out were the physically demanding character of the job, its complexity and increased scope of work, as well as the need for regular experience. In the education ministry's department for elementary education it was concluded that due to the complexity of the tasks, "our female staff mostly did not reach the point of being able to solve these issues." ${ }^{\prime 56}$ Due to such views, very few male staff was envisaged for the replacement and these were mainly attendants and male nurses.

\section{Collaborators as Employers}

The replacement of male by female staff in the institutions of the local administration had been contrary to their interests and endeavors from the beginning of the occupation. The female staff was then deprived of jobs in great numbers because of the need to reduce the existing administrative apparatus in order to comply with the needs of the reduced, occupied territory and make it more economical and efficient. On 29 May 1941, the collaborationist authorities brought a decree regulating the official relations of female staff in the state, regional and municipal administration, which envisaged the dismissal of married female civil servants who together with their husbands obtained minimum funds for a normal existence from their property or the husband's employment while otherwise they remained employed, working not for a salary, but

55 „Уредба о замењивању мушких радника и намештеника женама“, Обнова, 22. 9. $1943,5$.

56 AS, Ministarstvo prosvete i vera 1941-1944 (G-3), f. 695, II br. 920. 
for the amount of discrepancy to that minimum. The same applied to unmarried male and female civil servants, who together with their parents had minimum funds for their existence or remained employed for the sum of money up to that minimum. The minimum amount was determined by the finance ministry. Civil servants exempted from this decision were those who had reached retirement age as well as unmarried male civil servants having particular personal traits. Since the application of this decision did not satisfy the needs of reducing the number of civil servants, a decision on official relations of the people employed in the state, regional and municipal administration was published on 18 June 1941. This decision stipulated the retirement of all civil servants who acquired 30 years of service in the government administration or 60 years of age, as well as female civil servants who performed office service but had less than four grades of high school. Additionally, there was a possibility that "all civil servants, whose professions prove to be temporary or unnecessary due to the reorganization of the administration and newly established opportunities, could be made redundant by the decision of a competent commissar". ${ }^{57}$

These regulations caused great dissatisfaction among the civil servants, as many were left without jobs and livelihoods. The collaborationist authorities eased the suggested measures so that in July of 1941 unmarried male and female civil servants older than 35 were exempted from being dismissed.$^{58}$ One more commission was established, in charge of giving opinions regarding the petitions and appeals of the civil servants affected by these decisions. ${ }^{59}$

Even though there numerous appeals and complaints, these measures were upheld until the end of the occupation. Moreover, certain resources of the collaborationist government brought regulations limiting the employment of female staff. In case of experts, the possibility of employing women to executive positions was particularly excluded. ${ }^{60}$

57 „Одлука о службеним односима лица запослених у државној, бановинској и општинској служби“, Службене новине, 18. 6. 1941, 1.

58 „Одлука о изменама и допунама прописа о службеним односима државних, бановинских и општинских службеника“, Службене новине, 16. 7. 1941, 5.

59 „Одлука о сталној комсији за регулисање службених односа лица запослених у државној, бановинској и општинској служби“, Службене новине, 20. 6. 1941, 2.

60 The restriction in employment of women was particularly pointed out in the regulations on structuring the ministry of construction and ministry of post, telephone and telegraph. Olivera Milosavljević, Potisnuta istina. Kolaboracija u Srbiji 1941-1944, (Beograd: Helsinški odbor za ljudska prava u Srbiji, 2006), 227-228. 
According to the regulation on the removal of nationally unreliable officials, published in August of 1941, all government employees belonging to the communist organization or the Masonry were also left without employment, as well as those who spread false news and created confusion, showed a propensity for corruption, were negligent and unconscientious, as well as those who by "their activities contributed to pushing the country and its people into a miserable destructive war with the German Reich." ${ }^{61}$ These officials lost their rights to retirement while the families of war prisoners characterized as nationally unreliable lost the right to receive their income. Many women were affected by this regulation and were dismissed, not only because of their own standpoints, but due to family ties and friendships with members of the National Liberation Movement even if they were not communist-oriented themselves. ${ }^{62}$ Women who also lost their jobs were those who had family relationships with members of the Yugoslav Government-In-Exile and members of the Ravna Gora Movement. Keeping in service male and female civil servants who "on the basis of personal and official relations do not deserve consideration" was criticized by Milan Nedić, the president of the collaborationist government, who particularly pointed out the examples of a few women who were spouses of members of the Yugoslav Government-In-Exile as well as spouses of members of the Ravna Gora Movement and the National Liberation Movement and who were employed in the local administration. ${ }^{63}$

Male and female civil servants who were not Serbian nationals were also dismissed. The government of Milan Nedić insisted on these measures even though many departments tried to protect their employees. The general secretariat of the general educational council in particular pleaded not to dismiss a female civil servant "of French nationality, a Serbian citizen who had come to Serbia in the course of the last world war and spent 20 years in the civil service in Serbia." ${ }^{\prime 4}$ Male and female civil servants who were not Serbs but were married to Serbs were also kept in service.

61 „Уредба о уклањању национално непоузданих службеника из јавне службе“, Службене новине, 6. 8. 1941, 2.

62 That was the case of a female teacher whose husband was a political commissioner in the National Liberation unit while another female teacher was dismissed due to suspicions that prior to the war she was in a relationship with the teacher who later joined the National Liberation Movement. AS, G-3, f. 612, III pov. br. 1224/42.

63 AS, G-3, f. 482, III pov. br. 373.

64 Vojni arhiv (Military Archives - VA), Nedićeva arhiva (Nda), 34-9-57. 


\section{Case of Female Educators}

Among educated, employed women, educators were the most numerous. The collaborationist authorities had a special attitude toward them. They were under pressure due to widespread attitudes among educational authorities that women were not successful as educators. Employing female teachers in male schools was particularly avoided due to the belief that they do not have sufficient authority to achieve an educational impact on the students. Mistrust toward female teachers and opinions that they cannot perform well in male high schools were based on the belief that they did not have sufficient capabilities to "share their experience with male youths nor lead them successfully throughout their development and training for a national life." ${ }^{65}$ At the same time, the requests coming from villages demanded male teachers to work in their schools since it was considered that they would have greater authority and impact on the population. ${ }^{66}$

An indicator of how these opinions were widespread was the use of a special term "defeminization" for removing women from the educational profession. Many school principals advocated in favor of "defeminization" of secondary schools, especially high schools, stating that a large number of female teachers labeled the school faculty as "tepid, soft, sentimental, and overly sensitive, which has a negative educational impact on our male secondary-school youths." ${ }^{17}$ School principals were not the only ones who had such attitudes: at a meeting held in December of 1942, where the representatives of the University and other educational, scientific, and literary institutions analyzed the needs for the production of the Serbian Civil Plan, certain professors stood against the "feminization" of education. ${ }^{68}$

Except for the belief that women do not possess sufficient authority to work in education, the women engaged in education system were also exposed to criticism for being irresponsible and insufficiently devoted to their vocation. This was particularly evident after the education ministry ordered teachers to visit students during the winter in their flats and control their work and study at home due to the impossibility of conducting the lectures at schools because of a shortage of firewood. An anony-

65 Радиша Митровић, „Светосавска школа“, Просветни гласник, бр. 11, новембар 1942, 602-3.

66 AS, G-3, GPS, f. 1, p 2/38.

67 AS, G-3, f. 1019, III pov. br. 1200.

68 AS, G-3, GPS, f. 2, p 32/1942. 
mous letter with accusations against the female teachers who visited students' homes was sent to the education minister, who required all teachers to read it. ${ }^{69}$ Soon, female teachers were exposed to similar attacks in the press. They were accused of visiting the flats of students inappropriately dressed in short skirts and silk stockings, with excessive make-up, smoking constantly and expressing their dissatisfaction with the decree to make house visits. Newspaper articles pointed out that female teachers behaving in such a way had more money than they could earn with their regular salary and that they did not belong in the educational profession. ${ }^{70}$ The criticism of female teachers that used make-up and dressed inappropriately, making a negative educational impact on the pupils, was emphasized several times in the course of the occupation. ${ }^{71}$

Although they were criticized due to their insufficient dedication to their job, female teachers, as well as male teachers, were also expected to show support to the collaborationist authorities. They were required to stand out for the purpose of anti-communist propaganda and support the occupation and collaborationist policy. A special type of coercion in this sense could be seen in the organizations of anti-communist courses that had to be attended by members of the educational profession, as well as in the obligation to keep special political lectures to both students, and the population. ${ }^{72}$

Female educational workers as well as other women employed in the local administration were affected by the decision regulating the official relations of female staff in the state, regional and municipal administration, but it was difficult to apply this decision within the educational system without major consequences on certain institutions, which would have to suspend their work under these conditions. Not later than July and August of 1941, the decisions were made excluding professors and teachers of a series of educational institutions, as well as German language professors, from the application of this decision. ${ }^{73}$

69 VA, Nda, 165-6-10.

70 „Злоупотреба дужности“, Наша борба, 21. 12 1941, 10.

71 „Нов распис Министарства просвете односно учитељица“, Обнова, 1. 4. 1943, 5.

72 Ljubinka Škodrić, „Prosvetni radnici u ideologiji vlade Milana Nedića 1941-1944“, Istorija 20. veka 1/2011, 154-155.

73 The professors and teachers spared from dismissal were those at the Music Academy, the Academy of Fine Arts, Music High School and School for Applied Arts as well as those employed in the National Theatre in Belgrade and necessary female staff of the National Theater, the Music Academy and the Music High School, the Academy of Fine Arts, and the School for Applied Arts. „Две одлуке Савета комесара“, Службене 
The education ministry was receiving complaints for the dismissal of female educational workers for a long time. In Niš, an uneven application of prescribed decisions was criticized, which led to the fact that they were interpreted "superficially, wrongly, and without social criteria"74 and that many financially secured female teachers were kept, while those that were poor were dismissed. The local educational authorities in Požarevac reproached the mechanical approach to the regulation and emphasized that a qualitative selection should have been implemented rather than "dismissal of good, even excellent, and experienced female workers, together with those who did not work properly." Contrary to this, the education ministry criticized the fact that each county applied the regulations differently and that in certain places female teachers received full salaries while in other places, as it was prescribed, they received only the difference between the income of their spouse and the amount of minimum funds for their existence. ${ }^{75}$ At the same time, a wave of anonymous reports appeared against female teachers and professors who presented false data on their financial and property status. ${ }^{76}$ Devoted to their vocation, many female teachers were even ready to work for free just to be allowed to spend time with children. ${ }^{77}$

A certain number of dismissed educational workers subsequently were reinstated in the course of 1942, but priority was given to men. Only the most existentially endangered dismissed female teachers were rehired. ${ }^{78}$ At the beginning of 1942, female teachers married to war prisoners were given their jobs back, taking into account that they were allowed to receive only the difference between their salary and the compensation for their imprisoned husband.${ }^{79}$ Since in the course of 1942 the "minimum" amount was increased, some female teachers were given back their jobs and a certain number of retired female teachers were also re-activated. ${ }^{80}$ When employing refugees, as regards married couples, only male teach-

новине, 30. 7. 1941, 3; „Одлука Савета комесара о задржавању у служби особља Школе за примењену уметност у Београду“, Службене новине, 15. 8. 1941, 13.

74 AS, G-3, f. 484, III pov. br. 566.

75 AS, G-3, f. 609, III br. 14920.

76 AS, G-3, f. 892, II pov. br. 388/41.

77 Рад. Вл. Ђорђевић, „Писмо једне учитељице“, Наша борба, 22. 3. 1942, 4.

78 „Активирање учитеља народних школа“, Обнова, 4-6. 4. 1942, 6.

79 „Враћање у службу учитељица удатих за ратне заробљенике“, Обнова, 26. 1. $1942,7$.

80 AS, G-3, f. 136, I pov. br. 429/41. 
ers who were married were employed. In case of death of employed husbands, the dismissed female teachers were re-employed. ${ }^{81}$

\section{The Attitude Toward Employed Women}

The attitude of the collaborationist authorities toward employed women was based on their conservative views, which bracketed and subordinated the role of women within society. Work and employment of women were mainly perceived as their exposure to the perils of moral decline. These views had several nuances and there was a difference in attitude with regard to female workers employed in trade and industry and women who had higher education and who worked as office workers. Although a certain level of understanding was shown for the former and their work was considered as the existential necessity, in the first years of the occupation the views disapproving the employment of women were much more vociferous. This criticism was mainly based on the belief that women were insufficiently devoted to their work and that they used their workplace for emphasizing the attributes of their female sexuality, primarily through make-up, offensive dressing, and loose behavior. Except for female teachers, in October of 1941 female clerks in the education ministry were also criticized and being accused for coming to work dressed coquettishly, and the education minister ordered them to wear black aprons during their work hours. ${ }^{82}$ Make-up was extremely striking as a challenge to modesty and patriarchy. Campaign against the use of make-up by female civil servants was conducted through the public media while the working capacity of the women using make-up was derogated. ${ }^{83}$ Female civil servants were also criticized for alleged unkindness and laziness and they were blamed for spending their working hours mainly in primping and gossiping. ${ }^{84}$ Suggestions and warnings that women working in offic-

81 This was the procedure implemented for female teachers in Kragujevac whose husbands were shot in the reprisals in October of 1941. AS, G-3, f. 140, I br. 2132.

82 AS, G-3, f. 186, 10-65-41.

83 The prohibition of make-up in offices was supported in the press by the question "how can we seek our fast and determined regeneration, when the women who support its realization arrive in their offices painted" and followed by the remarks that "schools and offices require attention and great effort to work properly on a daily basis, not the women who are going to mirror themselves and check whether they have 'eaten' their lipstick or removed powder from their face during their office work. It was enough of dressing up and being foppish.” „Шминку треба забранити у свим надлештвима и свим школама“, Ново време, 7. 12. 1941, 6.

84 „Овакви више не смемо да будемо!“, Српски народ, 18. 9. 1942, 9. 
es should be dismissed were received repeatedly, often containing the explanation that they were implementing communist propaganda and obstructing the work process. ${ }^{85}$

Criticizing female civil servants for excessive beautification, unkindness, and insufficient devotion to work complied with the tendency of the collaborators to show the pre-war civil servants as irresponsible, corruptible, and greedy while representing their own policy as the termination of such a practice. ${ }^{86}$ In that respect the employment of women was criticized since, as it was represented as no less than a conspiracy devised for the purpose of their moral devastation. It was said that jobs were given to young and beautiful women who by getting employment were exposed to possible abuse at the workplace. ${ }^{87}$

At the same time, there was an awareness that for many women employment was a matter of existential necessity. ${ }^{88}$ Even upon the acceptance of the necessity of enabling women to work for the purpose of maintaining their livelihood, it was not really considered how the women who lost their jobs and did not have other means of income would maintain themselves. Thereby female workers were treated with more tolerance while the female civil servants were thought to be employed not only because of existential reasons, but also due to "personal desires." ${ }^{89}$ In that

85 Dragomir Jovanović, the administrator of the city of Belgrade, received a letter containing the following statements: "Female personnel are actually the worst in all offices. Those women are the most dangerous. They achieve all they want thanks to their skirts, the communists are aware of that and thereby hire them the most." IAB, Uprava grada Beograda - Specijalna policija (UgB, SP), IV-Q-314.

86 Nataša Milićević, „Činovnici u okupiranoj Srbiji 1941-1944“, Istorija 20. veka 2/2018, 74.

87 "A woman is wrenched from family, from the most supreme duty of motherhood and she is given a mattock and a spade. She is placed in front of a typewriter, hunched during a whole day, to serve a perverted boss. She became "equal" to a man. She "has emancipated herself". However, that is not all. "Emancipation" in an intellectual sense did not apply to all women. In order to obtain the position of civil servant, she had to meet certain preconditions. Without them, she could not take the exam. She had to be young and beautiful. In order to make a career, she had to pass through flatlets of many bosses, directors and members of Parliament.” Гојко Р. Вукчевић, „Мајка“, Наша борба, 17. 7. 1942, 11.

88 „Efforts should be made for women to leave work in factories and offices as soon as possible. That is not the place for women since we are aware that they work there only in order to earn a minimum funds neccesary for sustaining the existence. They are forced to perform those jobs, consequently not being able to perform their far more significant duties.“ Небесна Јојкић, „Каква мора да буде српска жена?“, Обнова, 12. 8. 1941, 4.

89 'Unfortunately, the 'mother-system' has been thrown out of upbringing nowadays. She is either a worker or a civil servant or 'a lady'. The first one left her natural, in- 
respect attention was mostly given to the standpoint that married women should not be employed and that husbands had to be the providers with sufficient earnings for maintaining the family. ${ }^{90}$ Additionally, it was also felt that employed women were a competition for men, that their entry into the job market devalued the professions, made less value of male work, and reduced the possibility of their employment. ${ }^{91}$

However, traditional image and expectations from Serbian women that were imposed to the public were gradually losing ground because of the need for their greater employment. A change of rhetoric of the collaborationist authorities was more broadly in compliance with German economic efforts to mobilize as much workforce as possible. Therefore, significant tensions occurred. Apart from criticizing the employment of women, increasingly expressed standpoints in public were those praising their working engagement. a compromise between these two standpoints was achieved by the affirmations that beside their hard work, employed women remained modest spouses and exemplary mothers. ${ }^{92}$ Kindergartens for children were founded for the purpose of helping the employed women who had small children. Particularly active in this respect was the Administration of the Fund of Army General Milan Nedić. ${ }^{93}$

At the same time, along with news articles propagating the complete devotion of women only to home and family, articles about the breakthrough of women into many exclusively male professions were also published. The press emphasized that the byword "that is not for women" is no longer valid in practice and that women took positions in the fields of engineering, science, and art as photographers, engineers, doctors, vets. ${ }^{94}$ Women working at Belgrade construction sites - women sawyers, were de-

herent duty by force of circumstances, due to poverty. The second one did the same by force of circumstances or because of personal desire, while the third one did it wantonly.” Владан Бијелић, „Породица као основ васпитања“, Наша борба, 22. 2. 1942, 10.

90 Хр. Магазиновић, „Наша анкета - Српска жена и њена будућност - Не тражите од сваке жене да буде домаћица и мајка, ако она зато није способна“, Обнова, 3. 9. 1941, 5.

91 "Her presence in the office reduces the price of men's efforts. Today, there is a multitude of unemployed men whose jobs women do at half the price.” Б. М., „Данашња жена", Наша жена, јун 1942, бр. 1.

92 Р. Милојевић, „Жена нове Србије“, Српски радник. Гласник Српске заједнице рада, 1. 9. 1943, 2. The same article was also published in the daily journal Novo vreme, 4. 9. 1943.

93 „Оснивање обданишта за децу запослених мајки“, Српски радник. Гласник Српске заједнище рада, 1.7.1943, 7.

94 „Жена данас“, Коло, 18. 4. 1942, 24. 
scribed as praiseworthy in the press and it was pointed out that the time had passed when women only cooked and patched socks. ${ }^{95}$

Newspaper articles in the collaborationist press pointed out that women could no longer live the way they lived earlier and that they had to be involved in a demanding life struggle for survival together with men. The standpoint gradually emerged about the necessity of female employment. Consequently, the media promoted the image of modest and hard-working women civil servants devoted to their work and duty. It was considered desirable for them to replace men who were performing military duty. Contrary to earlier images of female civil servants having excessive makeup and were dressed up, as well as morally fallen female workers, women were shown as exemplary employees who did not pay attention to dressing up and gossiping, were not interested in fashion but were dedicated to traditional values. Unlike earlier press coverage, which wrote about the substandard working contribution of women, articles praising their work were increasingly appearing. At the same time, there were also articles pointing out the successes of women in all sectors of life, from science and literature, to other spheres of work. Additionally, despite emphasizing that women could no longer be brought up as "refined ladies" and that by participating in different business activities women from Belgrade kept stride with women from other major European cities although not to an equal extent, the emphasis was that no successful woman neglected her maternal duties. ${ }^{96}$

\section{Conclusion}

Even though employment represents a cornerstone for women's emancipation, as well as their ability to generate an income, during the occupation it was primarily a requirement for their bare survival and the existence of their families. Employment made women feel safe and able to contribute to the family's existence. This was brought into question under the occupation by conditioning the position of women on the job market.

Unlike the conservative collaborationist government, the German occupation authorities gave priority to the employment and work of the entire population. New forms of employment under the occupation were evolving, such as working locally for the occupation authorities and going to Germany to conduct voluntary work. Increased war needs also re-

96 „Наше жене у јавном животу“, Ново време, 30. 3. 1943, 4. 
sulted in the tendency to impose mandatory work for women. The uncertainty of the status of employed women was reflected in different forms of coercion that they experienced in the course of the occupation. Women employed in the local administration were left jobless due to a reorganization and reduction of the number of employees, their salaries were reduced and they were exposed to strong ideological pressure. Women were also dismissed because of family relations or friendships with members of resistance movements or because of their ethnic affiliation. The quality of their work was underestimated and they were frequently criticized and disrespected in public as irresponsible workers.

The collaborationist authorities based their policy on conservative patriarchal ideas and emphasized the need for keeping women at home with their families. Thereby they did not take into account the fact that many women were forced to seek employment due to existential reasons, including the survival of those very families. The pressure of traditionalism caused the implementation of decisions referring to more intensive employment of women to be procrastinated and it also caused avoidance of their application despite the endeavors of the occupation authorities. Despite being significantly delayed, the need for wider involvement of women in the work process gradually prevailed over the ideological views. By the end of the occupation, this affirmative attitude toward the employment of women and their work increased, becoming visible mainly in newspaper articles. However, except for that, no significant changes occurred in the general perception of female employment, which was viewed negatively at the very beginning of the occupation.

\section{Summary}

It was extremely difficult for women to keep their jobs in the course of the occupation of Serbia in World War II. It called into question their very existence under the difficult wartime circumstances. Many women who had to earn a living worked for the occupation authorities or went to Germany for voluntary work even though they took the risk of being labeled as women of loose morals. Additionally, there were attempts to impose mandatory labor for women, which was contrary to the endeavors of the collaborationist authorities to reduce the role of women to family caregiving. Attempts to replace male with female civil servants were also countered from the beginning of the occupation by opposite tendencies. Many female civil servants were dismissed while only those whose jobs 
were their only source of income were retained. Women were dismissed due to family relations or friendships with members of resistance movements or based on their ethnic affiliation. The quality of their work was underestimated and they were frequently criticized and disrespected in public as irresponsible workers. The employment of women was limited and the possibility of achieving executive positions was out of the question. The occupation authorities' need for women's labor gradually prevailed over the ideological views of the collaborators, although with a significant delay. Thereby, the attitude toward the employed women and their working contribution started changing by the end of the war. Even though these changes were visible, their belated implementation and token character was rooted in distrust toward the employed women. This suspicion toward the quality and very principle of female labor remained a permanent fact of life for women in occupied Serbia.

\section{Sources and Literature}

- $\quad$ Arhiv Srbije: Predsedništvo Ministarskog saveta 1941-1944; Ministarstvo prosvete i vera 1941-1944; Zemaljska komisija Srbije za utvrđivanje zločina okupatora i njihovih pomagača 1944-1948; Zbirka dokumenata Bezbednosno-informativne agencije.

- $\quad$ Arhiv Jugoslavije. Emigrantska Vlada Kraljevine Jugoslavije 1941-1945.

- Istorijski arhiv Beograda: Zapovednik policije bezbednosti i službe bezbednosti - BdS; Upava grada Beograda - Specijalna policija.

- Vojni arhiv. Nedićeva arhiva.

- Aleksić, Dragan. Privreda Srbije u Drugom svetskom ratu. Beograd: Institut za noviju istoriju Srbije, 2002. (cyrillic)

- Aleksić, Dragan. „Problem radne snage u industriji i rudarstvu Srbije u Drugom svetskom ratu“. Tokovi istorije 3-4/1997, 89-110. (cyrillic)

- Božinović, Neda. Žensko pitanje u Srbiji u XIX i XX veku. Beograd: „Devedesetčetvrta“, „Žene u crnom“, 1996.

- Galić, Branka. „Žena i rad u suvremenom društvu - značaj 'orodnjenog' rada“. Sociologija i prostor 48/2011, 25-48. doi: 10.5673/sip.49.1.2

- Glišić, Venceslav. „Dosije o Veri Pešić ili kako ne treba pisati istoriju obaveštajca“. Vojnoistorijski glasnik 2/2009, 175-213. (cyrillic)

- Gudac Dodić, Vera. „Zapošljavanje žena u Srbiji i Jugoslaviji u drugoj polovini 20. veka“. Godišnjak za društvenu istoriju 1-3/2003, 87-105. (cyrillic) Janjetović, Zoran. Collaboration and Fascism Under the Nedić Regime. Belgrade: Institute for Recent History of Serbia, 2018.

- Janjetović, Zoran. U skladu sa nastalom potrebom... Prinudni rad u okupiranoj Srbiji 1941-1944. Beograd: Institut za noviju istoriju Srbije, 2012. 
- Janjetović, Zoran. U: „Na radnim zadacima'. Rad na stranicama kolaboracionističke štampe“. Kolaboracionistička štampa u Srbiji 1941-1944, priredio Aleksandar Stojanović, 337-358. Beograd: Filip Višnjić, 2015. (cyrillic)

- Kecman, Jovanka. Žene Jugoslavije u radničkom pokretu i ženskim organizacijama 1918-1941. Beograd: Institut za savremenu istoriju, Narodna knjiga, 1978.

- Kreso, Muharem. Njemačka okupaciona uprava u Beogradu 1941-1942. Sa osvrtom na centralne okupacione komande i ustanove za Srbiju, Jugoslaviju i Balkan. Beograd: Istorijski arhiv Beograda, 1979.

- Mazover, Mark. Hitlerovo carstvo. Nacistička vladavina u okupiranoj Evropi. Beograd: Arhipelag, 2019.

- $\quad$ Mazover, Mark. Mračni kontinent. Evropa u dvadesetom veku. Beograd: Arhipelag, 2011.

- $\quad$ Marković, Saša. Stazama smelih. Monografija narodnooslobodilačkog rata na području opštine Požarevac. Požarevac: Kulturno prosvetna zajednica opštine Požarevac, 1979. (cyrillic)

- Milošević, Božo. Sociološki temati o radu, obrazovanju i kulturi. Novi Sad: Prometej, Niš: Filozofski fakultet, 2016.

- Milenković, Milica. „Žene radnice u privredi Srbije 1918-1929. godine”. Srbija u modernizacijskim procesima 19. i 20. veka. Položaj žene kao merilo modernizacije II, naučni skup, ur. Latinka Perović, 218-226. Beograd: Institut za noviju istoriju Srbije, 1998.

- $\quad$ Milenković, Milica, Toma Milenković. Zapošljavanje u Srbiji, I: Od začetaka do oslobođenja zemlje 1944. Beograd: Republički zavod za tržište rada, 2002. (cyrillic)

- Milićević, Nataša. „Ishrana u okupiranom Beogradu 1941-1944“. Tokovi istorije 2/2012, 77-91. (cyrillic) doi: 10.31212/tokovi.2012.2.mil.77-91

- Milićević, Nataša. „Činovnici u okupiranoj Srbiji 1941-1944“. Istorija 20. veka 2/2018, 69- 86. doi: 10.29362/ist20veka.2018.2.mil.69-86

- Milosavljević, Olivera. Potisnuta istina. Kolaboracija u Srbiji 1941-1944. Beograd: Helsinški odbor za ljudska prava u Srbiji, 2006.

- $\quad$ Schmid, Sanela. „Serbian Civilian Workers in Nuremberg 1941-1945“. Forced Labour in Serbia. Producers, Consumers and Consequences of Forced Labour 1941-1944, eds Milovan Pissari, Sanela Schmid, 82-109. Belgrade: Center for Holocaust Research and Education, 2018.

- $\quad$ Simonton, Deborah. A History of European Women`s Work. 1700 to the Present. London, New York: Routledge, 1998.

- Stibbe, Matthew. Women in the Third Reich. London: Bloomsbury Academic, 2003.

- Svakodnevni život pod okupacijom 1941-1944. Iskustvo jednog Beograđanina, priredili Nataša Milićević, Dušan Nikodijević. Beograd: Institut za noviju istoriju Srbije, 2011. (cyrillic) 
- Škodrić, Ljubinka. „'Društvena odgovornost srpske žene za naš državni slom'. Žensko pitanje u kolaboracionističkoj štampi“. Kolaboracionistička štampa u Srbiji 1941-1944, priredio Aleksandar Stojanović, 289-311. Beograd: Filip Višnjić, 2015. (cyrillic)

- Škodrić, Ljubinka. „Prosvetni radnici u ideologiji vlade Milana Nedića 1941-1944“. Istorija 20. veka 1/2011, 151-162. doi: 10.29362/ist20veka.2011.1.sko.151-162

- Vinen, Richard. The Unfree French. Life under the Occupation. London: Penguin, 2007.

- Kolo (cyrillic)

- $\quad$ List uredaba za okupiranu srpsku teritoriju (cyrillic)

- Naša borba (cyrillic)

- Naša žena (cyrillic)

- Novo vreme (cyrillic)

- Službene novine (cyrillic)

- $\quad$ Srpski narod (cyrillic)

- $\quad$ Srpski radnik. Glasnik Srpske zajednice rada (cyrillic) 


\title{
Резиме
}

\author{
Љубинка Шкодрић
}

\section{Жене и плаћени рад у окупираној Србији 1941-1944. Политика колаборационистичких и окупационих власти}

\begin{abstract}
АпстРАкт: Чланак анализира јавну сферу рада жена у окупираној Србији током Другог светског рата. Разматрани су политика и ставови колаборационистичких и окупационих власти према запосленим женама, услови плаћеног рада жена, њихов положај, могућности и начини радног ангажовања. Рад је писан на основу архивске грађе, штампе и литературе.

КљУчнЕ РЕчи: жене, рад, запошљавање, добровољан рад, обавезан рад, службенице, просветне раднице, окупација, колаборација, Други светски рат
\end{abstract}

Женама је током окупације Србије у Другом светском рату било изузетно тешко да задрже радна места, што је пресудно утицало на њихову егзистенцију у тешким материјалним условима. Велики број жена које су морале да зарађују за живот налазио је посао у служби окупационих власти или су одлазиле на добровољан рад у Немачку иако су тиме ризиковале да буду обележене као неморалне. Осим тога, постојали су и покушаји да им се наметне обавезан рад, а то је било у супротности са настојањем колаборационистичких власти да се улога жена сведе на старање о породици и стога су ти покушаји стално спречавани. Онемогућени су и покушаји да се мушки службеници замене женама пошто су од почетка окупације испољаване супротне тенденције - знатан број службеница је отпуштен, а задржане су само оне којима је запослење представљало једини извор егзистенције. Жене су отпуштане и због родбинских и пријатељских веза са припадницима покрета отпора и на основу националне припадности. Квалитет њиховог рада је потцењиван, а оне су у јавности често критиковане и омаловажаване као несавесне раднице. Запошљавање њих је ограничавано, а могућност стицања руководећих позиција за њих је била искључена. Потреба окупационих власти за радним ангажовањем жена је постепено, иако са значајним 
закашњењем, односила превагу над идеолошким ставовима колаборациониста. Услед тога се мењао однос према запосленим женама и њиховом радном доприносу. Иако су ове промене биле видљиве, њихова касна појава, али и декларативност утицале су на то да су неповерење и сумња у квалитет женског рада остајали трајна карактеристика живота жена у окупираној Србији. 
